\title{
Development of oestrogen receptor expression and hormone response in the uterus of the bovine fetus
}

\author{
J. R. Malayer and V. M. Woods \\ Department of Infectious Disease and Physiology, College of Veterinary Medicine, \\ Oklahoma State University, Stillwater, Oklahoma 74078-0350, USA
}

\begin{abstract}
The objective of the present study was to determine the temporal expression of oestrogen receptor $\alpha$ in the uterus of the developing bovine fetus. Bovine fetuses were collected and approximate gestational age was determined by crown-rump measurement. Fetal uteri were either snap frozen in dry ice-ethanol, or placed in sterile Dulbecco's modified Eagle's medium. Fetal uteri $(n=20)$ were homogenized and cytosolic oestrogen receptor measured by $\left[{ }^{3} \mathrm{H}\right]$ ligand binding assay. Total RNA was extracted from fetal uteri $(n=53)$ and amplified by reverse transcription-polymerase chain reaction using primers specific for the oestrogen receptor, progesterone receptor, interleukin $1 \alpha$, interleukin 6 , transforming growth factor $\beta$, prolactin receptor, epidermal growth factor receptor, retinoic acid receptor isoforms $\alpha, \beta$, and $\gamma$, or glyceraldehyde-3-phosphate dehydrogenase (loading control). Expressed as a ratio with glyceraldehyde-3-phosphate dehydrogenase, mRNA encoding oestrogen receptor was identified in fetal uteri throughout the period from day 65 to day 200 , and was increased from day 100 to day $185(P<0.003)$; uterine samples from day 100 to day 200 expressed interleukin $1 \alpha$, interleukin 6 , transforming growth factor $\beta$, prolactin receptor, epidermal growth factor receptor and retinoic acid receptor isoforms $\alpha, \beta$, and $\gamma$, but did not express detectable mRNA encoding progesterone receptor. Despite the presence of mRNA encoding oestrogen receptor, $\left[{ }^{3} \mathrm{H}\right]$ oestradiol binding was not detected until after day 155 . Fetal uterine explants collected at days 100-110 $(n=3)$ or at days 185-200 $(n=3)$ were cultured in the presence of oestradiol $\left(1.0 \mathrm{nmol} \mathrm{l}^{-1}\right.$, or vehicle); there was a significant effect of oestradiol treatment on specific mRNA expression at days $185-200(P<0.014)$, but not at days $100-110(P=0.71)$. It is concluded that mRNA encoding oestrogen receptor is constitutively expressed at least from day 65 in the uterus of the bovine fetus, but that oestrogen receptor $\alpha$ protein and a functional oestrogen response are not present until late in the second third of pregnancy.
\end{abstract}

\section{Introduction}

Oestrogens are known to play a role in the maintenance of normal pregnancy (Challis and Olson, 1988) but the physiological effects of oestrogens on the developing conceptus have not been clearly established. The developing conceptus of several species, including cattle, sheep, goats, mice and humans, is exposed to significant concentrations of oestrogens at various times during fetal life. In cattle, oestrogens are present in the fetal-placental compartment from about day 60 until the end of gestation (Challis et al., 1974; Robertson and King, 1979; Evans and Wagner, 1981; Robertson et al., 1985; Tsumagari et al., 1993). The roles of these oestrogens are unclear, and it is not known which factors modulate their activity.

In general, the biological effects of oestrogens and other steroid hormones are mediated through specific receptors located within the cell nucleus which operate as ligand-induced

Received 6 June 1997. transcription factors (Gorski, 1986; Beato, 1989; O'Malley, 1990). In addition, these receptors have increasingly been implicated in multifactorial regulatory schemes involving multiple intracellular signalling pathways (Katzenellenbogen, 1996). It is reasonable to expect that specific effects of oestrogens in fetal development are correlated with the appearance of these receptors in target tissues; it is also possible that actions of effectors other than oestrogens, mediated by second messenger pathways through the oestrogen receptor (Katzenellenbogen, 1996), are correlated with the appearance of the oestrogen receptor. Oestrogen receptors, identified by a variety of methods, are present virtually throughout embryonic and fetal life in the mouse. Messenger RNA (mRNA) encoding oestrogen receptor has been found in mouse oocytes and blastocysts and oestrogen receptor is present in embryos at day 10 of gestation (Hou and Gorski, 1993). Oestrogen receptor appears in the reproductive tracts of both male and female fetuses as early as day 13 of gestation (Greco et al., 1991; Greco et al., 1992), during the sexually ambiguous stage 
of reproductive tract development. The appearance of oestrogen receptor in fetal development has been examined in mice (Greco et al., 1991; Greco et al., 1992), guinea-pigs (Pasqualini et al., 1980) and humans (Glatstein and Yeh, 1995). A second oestrogen receptor type, termed oestrogen receptor $\beta$, has been recognized in addition to the previously described receptor, now referred to as oestrogen receptor $\alpha$; the present study dealt exclusively with oestrogen receptor $\alpha$.

Prenatal exposure to oestrogen has been cited as the cause of clear cell adenocarcinoma and other abnormalities of the reproductive organs of men and women (Herbst et al, 1971, 1977). Similar oestrogen-induced abnormalities have been observed in rodent models (McLachlan et al., 1975, 1980; Newbold et al., 1983, 1985, 1986). Since these disruptions in the offspring are seen only postpubertally, when gonadal steroids are present, one possible explanation is that the steroid response network has been affected by exposure to oestrogen during fetal development. Teratogenic effects of oestrogenic plant toxins have been described in sheep and pigs, and a variety of oestrogenic plant materials have been shown to adversely affect reproductive performance in pubertal and adult cattle, sheep, and pigs (Livingston, 1978; Weaver et al, 1986; Diekman and Green, 1992). Little is known about the developmental role that steroids may play in the programming and activation of the genomic components of the fetal reproductive tract and their relation to subsequent growth and fertility in adult life. The aim of the present study was to examine the ontogeny of oestrogen receptor $\alpha$ in the fetal reproductive tract during development through characterization of the appearance of mRNA encoding oestrogen receptor $\alpha$, as well as the development of a functional oestrogenic hormone response determined by detection of specific oestrogen ligand binding and hormone-dependent modulation of specific target gene expression.

\section{Materials and Methods}

\section{Tissue collection and sample preparation}

For detection of mRNA encoding oestrogen receptor $\alpha$ and ligand binding studies, uteri were collected from pregnant, crossbred beef cows $(n=135)$ at a commercial abattoir. The duration of gestation was estimated by fetal crown-rump measurement (Rexroad et al., 1974) and fetal uteri were dissected free of adipose and connective tissue. Fetal uteri collected for analysis of mRNA $(n=53)$ and ligand binding $(n=20)$ were placed in sterile vials, snap-frozen in a bath of dry ice and ethanol, transported to the laboratory on dry ice, and stored in liquid nitrogen.

Total RNA from mammary gland tissue of lactating Holstein-Freisian cows (a gift of J. Gorski and D. Gregg, University of Wisconsin, Madison) was used in reverse transcription-polymerase chain reaction (RT-PCR) to isolate and subclone cDNAs encoding oestrogen receptor $\alpha$ and progesterone receptor for use as probes and as positive controls in the experiments described below. Specific primers based on the sequence of the rat oestrogen receptor $\alpha$ and progesterone receptor were used to amplify a portion of the bovine cDNAs (Table 1). These amplification products were resolved on $2 \%$ agarose-TAE gels $\left(40 \mathrm{mmol}\right.$ Tris-acetate $\mathrm{I}^{-1}$, I mmol EDTA $\mathrm{l}^{-1}$ ) and individual bands were excised from the gel. The cDNAs were then extracted and ligated into the Bluescript ${ }^{\text {(iii) }}$ cloning vector (Stratagene, La Jolla, CA) and the sequence of each was determined by dideoxy chain termination (Applied Biosystems, Foster City, CA; Model 373A Automated Sequencer, OSU Recombinant DNA/Protein Resource Facility).

For studies on the response of fetal uterine tissue to oestradiol, uteri were collected from pregnant females and the duration of gestation was estimated by fetal crown-rump measurement (Rexroad et al., 1974). Fetal uteri collected from pregnant females at days $100-110(n=3)$ or days $185-200$ of gestation $(n=3)$, estimated by fetal crown-rump measurement, were dissected free of adipose and connective tissue, placed in sterile tubes containing phenol red-free Dulbecco's modified Eagle's medium (DMEM) supplemented with $1 \times$ antibioticantimycotic solution (ABAM; Gibco-BRL, Gaithersburg, MD), $5 \mathrm{mmol}$ Hepes $\mathrm{l}^{-1}$ (Sigma, St Louis, MO) and sodium bicarbonate (Sigma), and transported to the laboratory.

\section{Ligand binding}

Homogenates of fetal uteri $(n=20)$ were tested for specific $\left[{ }^{3} \mathrm{H}\right]$ ligand binding as described by Kassis et al. (1984a). Briefly, frozen tissue samples were washed in ice-cold TED buffer

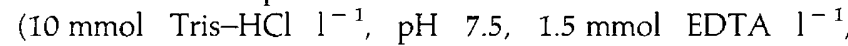
$0.5 \mathrm{mmol}$ dithiothreitol $1^{-1}$ (DTT; Sigma)) and then homogenized in ice-cold TSDG buffer ( 10 mmol Tris-HCl ${ }^{-1}, \mathrm{pH} 7.5$, $50 \mathrm{mmol} \mathrm{NaCl} \mathrm{l}^{-1}, 1 \mathrm{mmol}$ DTT $\mathrm{l}^{-1}, 10 \%(\mathrm{v} / \mathrm{v})$ glycerol) on dry ice. The homogenates were centrifuged at $368000 \mathrm{~g}$ for 90 min at $4^{\circ} \mathrm{C}$ (SW 55 Ti rotor; Beckman Instruments, Fullerton, CA). The cytosolic fraction was harvested and the protein concentration was determined (Bradford, 1976). The protein concentration in cytosols was normalized to $3-4 \mathrm{~g} \mathrm{l}^{-1}$ for determination of oestrogen receptor $\alpha$ ligand binding. Samples from early gestation fetuses (before day 110 of gestation) of the same crown-rump length were pooled to keep the total protein concentration within the range of $3-4 \mathrm{~g} \mathrm{l}^{-1}$.

Cytosols were incubated in duplicate tubes with various concentrations of $\left[{ }^{3} \mathrm{H}\right]$ oestradiol $\left(2,4,6,7\left[{ }^{3} \mathrm{H}\right]\right.$ oestradiol; specific activity $100 \mathrm{Ci} \mathrm{mmol}^{-1}$; Dupont NEN, Boston, MA) in the presence or absence of 200 -fold excess unlabelled diethyl stilboestrol (Sigma) for $16 \mathrm{~h}$ at $4^{\circ} \mathrm{C}$. The oestrogen receptorbound $\left[{ }^{3} \mathrm{H}\right]$ ligand was separated from the free ligand by hydroxylapatite (BioRad, Hercules, CA) chromatography, samples were extracted with ethanol, and the $\left[{ }^{3} \mathrm{H}\right]$ oestradiol was quantified by scintillation spectroscopy.

\section{Explant culture}

Fetal uteri were washed in DMEM, cut into $2-4 \mathrm{~mm}^{3}$ pieces and divided among six wells of a six-well culture plate (Becton-Dickinson Labware, Franklin Lakes, NJ). Explant cultures were maintained at $37^{\circ} \mathrm{C}$ in a humidified atmosphere of $95 \%$ air, $5 \% \mathrm{CO}_{2}$. These explants were incubated in phenol red-free DMEM supplemented with $1 \times A B A M, 5 \mathrm{mmol}$ Hepes $1^{-1}$, and sodium bicarbonate, plus $10 \% 3 \times$ dextran charcoal-stripped bovine fetus serum (CS-FBS; Hyclone, 
Logan, UT). Dextran-charcoal stripping was performed as described by Horwitz et al. (1976). Duplicate wells were also supplemented with $1 \mathrm{nmol}$ oestradiol $1^{-1}$, or ethanol vehicle and tissue was incubated for $24 \mathrm{~h}$. After incubation, tissue was homogenized and total RNA was extracted from explant culture samples by single-step extraction (Chomczynski and Sacci, 1987) to determine the presence of specific mRNA species by reverse transcription-polymerase chain reaction.

\section{Determination of oestradiol in charcoal stripped bovine fetus serum}

The concentration of oestradiol was determined in the CS-FBS used in explant culture experiments, and compared with the oestradiol concentration before the dextran-charcoal extraction. Concentrations of unconjugated oestradiol were determined by direct radioimmunoassay using the Coat-aCount $^{(\mathrm{R})}$ direct radioimmunoassay kit (Diagnostic Products Corp., Los Angeles, CA). Standard curves were prepared in charcoal-extracted adult cow plasma. Recovery of oestradiol added to samples was $89 \%$; sensitivity of the assay was $0.5 \mathrm{pg} \mathrm{ml}^{-1}$.

\section{Reverse transcription-polymerase chain reaction}

RT-PCR was the method of choice to maximize detection sensitivity of transcripts in the small amounts of RNA obtainable from individual fetal uteri. Tissue samples were homogenized in ice-cold buffer on dry ice and total RNA was extracted from frozen tissue or explant culture samples (Chomczynski and Sacci, 1987). Two micrograms of total RNA was denatured by heating to $95^{\circ} \mathrm{C}$ and reverse transcribed in the presence of random hexamers $\left(\mathrm{pdN}_{6} ; 100\right.$ pmole; Pharmacia, Piscataway, NJ), dATP, dTTP, dCTP, and dGTP (dNTPs; $1 \mathrm{mmol} \mathrm{l}^{-1}$; Pharmacia), $\mathrm{MgCl}_{2}$, RNase inhibitor (20 U per reaction; Promega, Madison, WI), and reverse transcriptase (Superscript $^{(i i N}, 200 \mathrm{U}$ per reaction; Gibco-BRL) at $37^{\circ} \mathrm{C}$ for $75 \mathrm{~min}$. The reaction was stopped by heating to $95^{\circ} \mathrm{C}$. Aliquots of reverse transcribed $\mathrm{CDNA}(1-5 \mu \mathrm{l})$ were denatured by heating to $95^{\circ} \mathrm{C}$ and subjected to polymerase chain reaction in the presence of 75 pmole specific primers (Table 1), $\mathrm{MgCl}_{2}$, 1 mmol dNTPs $\mathrm{l}^{-1}$, and Amplitaq ${ }^{(\mathrm{iN})}$ DNA polymerase $0.5 \mathrm{U}$ per reaction; Perkin-Elmer, Foster City, CA). Products of RT-PCR were resolved on agarose-TAE gels and quantified by scanning densitometry followed by image analysis using Image 1.60 software (NIH, Washington DC). Relative concentrations of products are reported as the ratio of the target cDNA amplicon to the glyceraldehyde-3-phosphate dehydrogenase (GAPDH) amplicon, which was used as a loading control. The mean values of these ratios were then subjected to analysis of variance to test the effect of gestational age and, in the case of tissue explants, hormone treatment on the quantity of product generated. Representative RT-PCR products from each primer (Table 1) were excised from agarose gels, subcloned, subsequently tested by dideoxy chain termination sequencing (Applied Biosystems, Model 373A Automated Sequencer, OSU Recombinant DNA/Protein Resource Facility), and the identity of each product verified in a sequence homology analysis using the Basic Local Alignment Search Tool (BLAST; Altschul et al., 1990).

\section{Transient transfection experiment}

The response, after oestradiol stimulation, from a transiently transfected oestrogen-responsive reporter plasmid pERE15 (Klock et al., 1987) was tested to investigate the functional oestrogen response in fetal-uterine cells. pERE15 contains the consensus, palindromic oestrogen response element (ERE) from Xenopus vitellogenin A2 (AGG TCA CAG TGA CCT), and the herpes simplex virus thymidine kinase promoter driving expression of the chloramphenicol acetyltransferase (CAT) coding region. The activation of the pERE15 reporter is a sensitive and specific assay to examine the appearance of functional oestrogen receptor $\alpha$ activity. The plasmid was inserted by cationic liposome-mediated transfection (Transfectam ${ }^{10}$; Promega) into enzymatically dispersed bovine fetus cells prepared from fetal uteri collected at day 185 of gestation. After a $24 \mathrm{~h}$ recovery period in DMEM supplemented with $10 \%$ CS-FBS, cells were refed using medium supplemented with 10\% CS-FBS and incubated for $48 \mathrm{~h}$. Cells were then incubated in the presence of $1.0 \mathrm{nmol}$ oestradiol $\mathrm{l}^{-1}$ for a further $24 \mathrm{~h}$ and tested for a response characterized by increased CAT transcription.

Chloramphenicol acetyltransferase activity was assayed in cell lysates by incubation in the presence of $\left[{ }^{3} \mathrm{H}\right]$ chloramphenicol and n-butyryl-coenzyme $A$, and then measuring the acetylated $\left[{ }^{3} \mathrm{H}\right]$ chloramphenicol present in the organic (xylene) phase after two-phase partitioning (CAT Enzyme Assay System Kit; Promega). The radioactivity present in the acetylated chloramphenicol was determined by scintillation spectroscopy. Enzyme activity in duplicate cell cultures was compared with that in cells transfected with pERE15 without subsequent oestradiol exposure as a negative control; $\left[{ }^{3} \mathrm{H}\right]-$ chloramphenicol was also measured in the xylene phase after extraction in the absence of cell lysates to determine background radioactivity after two-phase partitioning.

\section{Statistical analysis}

Results from ligand binding studies were pooled into groups $(n>3)$ representing 10 day intervals from day 80 to day 200 of gestation and subjected to one way analysis of variance (Steel and Torrie, 1980). Differences in mean values for ligand binding among groups were examined by paired $t$ tests. Total RNA yields from explant cultures and the relative concentrations of PCR products, given as the ratio of the target CDNA amplicon to the GAPDH amplicon, were subjected to analysis of variance using oestradiol treatment and gestational age as main effects. Expression of the GAPDH amplicon was analysed to determine the correlation between detected amounts of amplified product and the number of cycles of PCR used in the amplification, as well as by analysis of variance using oestradiol treatment and gestational age as main effects. 


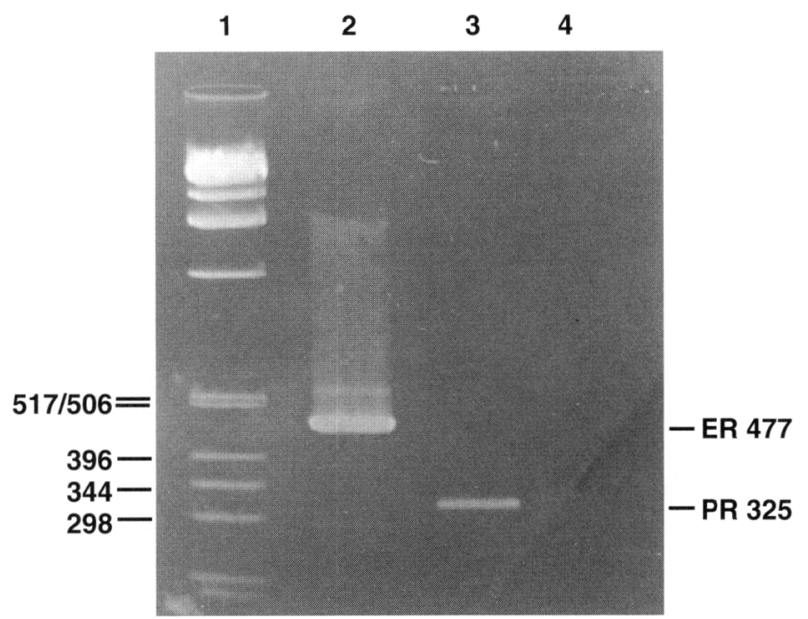

Fig. 1. Ethidium bromide-stained agarose gel of amplified cDNA products representing regions of the oestrogen receptor $\langle E R\rangle \alpha$ and progesterone receptor (PR) coding regions generated by RT-PCR from mammary gland tissue of mature cows. A $477 \mathrm{bp}$ fragment within the region coding the hormone-binding domain of the bovine oestrogen receptor $\alpha$ and a 325 bp fragment within the region coding the hormone-binding domain of the bovine progesterone receptor were amplified by PCR, isolated and sequenced. Amplified cDNA products representing portions of the oestrogen receptor $\alpha$ and progesterone receptor coding regions generated from mammary gland tissue of mature cows are shown in lanes 2 and 3, respectively. The reaction blank (lane 4) was subjected to RT-PCR in the absence of RNA as a negative control. Lane I: ladder.

\section{Results}

\section{Sequence of cDNA encoding bovine oestrogen receptor}

A 477 bp fragment within the region coding the hormonebinding domain of the bovine oestrogen receptor $\alpha$ was amplified by PCR, isolated and sequenced. Amplified cDNA products representing portions of the oestrogen receptor $\alpha$ and progesterone receptor coding regions generated from mammary gland tissue of mature cows are shown (Fig. 1). On the basis of the positions of the conserved primer sequences derived from the rat oestrogen receptor $\alpha$ used to generate the partial cDNA (Table 1 ) as well as the conservation in oestrogen receptor $\alpha$ gene organization observed in all species examined to date including mammals, birds and amphibians (Nestor et al., 1994 and references therein), this $477 \mathrm{bp}$ fragment spanned exons V to VII of the bovine oestrogen receptor $\alpha$ gene encompassing the hormone-binding domain. In addition, the base pair sequence of this fragment (GenBank Accession number U64962) bore $91 \%$ homology with the human oestrogen receptor $\alpha$ sequence over the same region, $93 \%$ homology with pig oestrogen receptor $\alpha$, and $89 \%$ homology with rat oestrogen receptor $\alpha$. The translated amino acid sequence exhibited $87 \%$ identity with human oestrogen receptor $\alpha$, $86 \%$ identity with pig oestrogen receptor $\alpha$, and $87 \%$ identity with rat oestrogen receptor $\alpha$. In contrast to oestrogen receptor $\alpha$, this fragment exhibited $<65 \%$ homology with rat oestrogen receptor $\beta$ over the most closely aligned region. There was a similar high degree of homology between the sequence of the isolated progesterone receptor fragment (Fig. 1) and the progesterone receptor sequences reported in other species.

\section{Appearance of $m R N A$ encoding oestrogen receptor in bovine fetal} uteri

A semi-quantitative reverse transcription PCR (RT-PCR) assay was used to determine the presence of mRNA encoding oestrogen receptor $\alpha$ in bovine fetal uteri collected between day 60 and day 200 of gestation. Relative concentrations of products are reported as the ratio of the target cDNA amplicon to the GAPDH amplicon, which was used as a loading control. The amplification of GAPDH was linear with increased number cycles of PCR over the range of cycle numbers used in these experiments ( $25-35$ cycles; $r>0.94$ in three independent tests); there was no effect of gestational age $(P>0.17)$ or treatment with oestradiol $(P>0.40)$ on the amount of the GAPDH amplification product observed. Working backwards from day 200 of gestation, mRNA encoding oestrogen receptor $\alpha$ was detected in the uteri of multiple fetuses at days 200, 190, 180, $160,140,120,110,100,90,84$, and 72 of gestation (Fig. 2). RNA samples from several uteri collected between day 100 and day 160 of gestation were predigested with DNase I (RQI RNase-free DNase I; Promega) before RT-PCR to verify that amplification products were not the result of contaminating genomic DNA. Amplification of the $477 \mathrm{bp}$ product was found to be unaffected by DNase I pretreatment (data not shown). In contrast to tissues from female fetuses, cells and tissues obtained from the reproductive organs of male fetuses at day 105 to day 120 of gestation $(n=3)$ did not contain detectable amounts of mRNA encoding oestrogen receptor $\alpha$ (data not shown).

\section{Oestradiol ligand binding activity in bovine fetal uteri}

Since expression of mRNA encoding oestrogen receptor $\alpha$ does not necessarily indicate functional receptor, homogenates of frozen tissue samples were tested for specific $\left[{ }^{3} \mathrm{H}\right] \mathrm{ligand}$ binding as described by Kassis et al. (1984a). There was a significant effect of gestational age upon ligand binding capacity $(P<0.001)$. There was significant increase in $\left[{ }^{3} \mathrm{H}\right]$ oestradiol binding between day 155 and day 165 of gestation $(P<0.031)$, between day 165 and day 185 of gestation $(P<0.03)$, and between day 185 and day 200 of gestation $(P<0.028)$ (Fig. 3). After day 160 of gestation, plots of specific $\left[{ }^{3} \mathrm{H}\right]$ oestradiol binding versus increasing concentrations of oestradiol showed saturable binding (Fig. 4). Before that time, despite the presence of mRNA encoding oestrogen receptor $\alpha$, there was minimal detectable $\left[{ }^{3} \mathrm{H}\right]$ oestradiol binding. Data from uterine tissue from day 185 of gestation was plotted as a Scatchard transformation (Scatchard, 1949). The $\left[{ }^{3} \mathrm{H}\right]$ oestradiol bound to a single type of site with a dissociation constant near $0.3 \mathrm{nmol} \mathrm{l^{-1 }}$ (Fig. 4, inset).

\section{Hormone stimulation by oestradiol in bovine fetal uteri}

Oestradiol concentration in FBS before dextran-charcoal extraction and in the CS-FBS used in cultures was $2 I$ and $<0.5 \mathrm{pg} \mathrm{ml}^{-1}$, respectively. At days $100-110$ of gestation, total RNA $\mathrm{mg}^{-1}$ tissue (wet mass) was lower $(P<0.01)$ than at 
Table 1. Sequences of primers used in the RT-PCR assay

\begin{tabular}{|c|c|}
\hline mRNA species & Primer nucleotide sequence \\
\hline Glyceraldehyde-3-phosphate dehydrogenase & $\begin{array}{l}\text { 5'-CCTTCATTGACCTTCACTACATGGTCTA-3' } \\
\text { 5'-GCTGTAGCCAAATTCATTGTCGTTACCA-3' }\end{array}$ \\
\hline Interleukin $1 \alpha$ & $\begin{array}{l}5^{\prime} \text {-GAAATTTGACATGGTTGCTTGCTTATGTATCA-3' } \\
5^{\prime} \text {-CTATTTTTCCAATATCTGAAAGTCAGTG-3' }\end{array}$ \\
\hline Interleukin 6 & $\begin{array}{l}5^{\prime} \text {-ATGAACTCCCGCTTCACAAGCGCCT-3' } \\
5^{\prime} \text {-CCAGCTACTTCATCCGAATAGCTC-3' }\end{array}$ \\
\hline Transforming growth factor $\beta$ & $\begin{array}{l}5^{\prime} \text {-GCTCCACGGAGAAGAACTGCT-3' } \\
5^{\prime} \text {-AGGAGCGCACGATCATGTTGG-3' }\end{array}$ \\
\hline Prolactin receptor & $\begin{array}{l}5^{\prime} \text {-GCAGATGGAGGACTTCCTACCAATTA-3' } \\
5^{\prime} \text {-GCAGGTCACCATGCTATAGCCCTT-3' }\end{array}$ \\
\hline Epidermal growth factor receptor & $\begin{array}{l}5^{\prime} \text {-CAGCGCTACCTTGTCATTCA-3' } \\
5^{\prime} \text {-AAGTCCTGCTGGTAGTCAG-3' }\end{array}$ \\
\hline Oestrogen receptor & $\begin{array}{l}\text { 5'-GAGATCCTGATGATTGGTCT-3' } \\
5^{\prime} \text {-CATCTCCAGCAGCAGGTCAT-3' }\end{array}$ \\
\hline Progesterone receptor & $\begin{array}{l}\text { 5'-CCCACAGGAGTTTGTCAAGCTC-3' } \\
\text { 5'-TAACTTCAGACATCATTTCCGG-3' }\end{array}$ \\
\hline
\end{tabular}

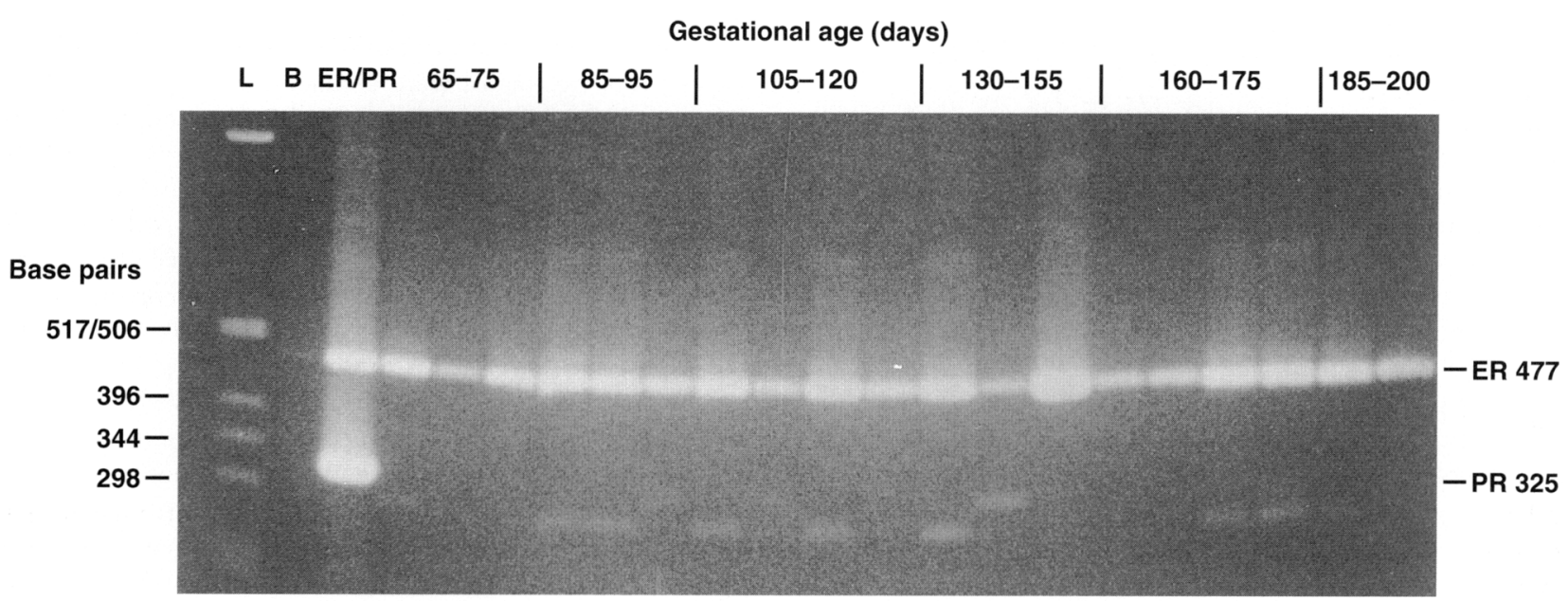

Fig. 2. Ethidium bromide-stained agarose gel of RT-PCR analysis to detect the presence of specific mRNAs encoding oestrogen receptor (ER) $\alpha$ and progesterone receptor (PR) in fetal uteri from day 65 to day 200 of gestation. Each lane represents RT-PCR amplification of products from a single animal within the estimated gestational age specified; these 18 examples are representative of results from a total of 53 individual fetuses between day 65 and day 200 of gestation. Primers shown in Table I were used and a 477 bp fragment of the bovine oestrogen receptor $\alpha$ (ER 477) and a 325 bp fragment of the bovine progesterone receptor (PR 325 ) were amplified by 35 cycles of PCR. Messenger RNA encoding oestrogen receptor $\alpha$ was present at all times from day 65 to day 200 of gestation; while amplification of the 325 bp progesterone receptor positive control cDNA fragment was clearly detectable (lane 3) but mRNA encoding progesterone receptor was not consistently detectable in fetal uteri by RT-PCR analysis during the period from day 65 to day 200 of gestation. The reaction blank $(B)$ was subjected to $R T-P C R$ in the absence of RNA. L: ladder.

days $185-200$ of gestation and was not affected by oestradiol treatment. At days 185-200 of gestation, there was an increase in total RNA in the oestradiol-treated tissue (age $\times$ treatment interaction, $P<0.06$ ) indicative of a generalized increase in RNA synthesis in response to oestradiol at the end of the second third of pregnancy.

In addition to a generalized increase in RNA synthesis, oestradiol was expected to increase progesterone receptor gene expression in fetal uterine explants in the presence of a functional receptor system. Messenger RNA encoding oestrogen receptor $\alpha$ was present in tissue explants at days $100-110$ and days 185-200 of gestation (Fig. 5); however, mRNA encoding progesterone receptor was not detectable by RT-PCR analysis in tissue examined directly (Fig. 2), or in either vehicle-treated or oestradiol-treated explants (Fig. 5), regardless of gestational age.

Fetal uterine explants expressed detectable concentrations of mRNA encoding oestrogen receptor $\alpha$, transforming growth factor- $\beta$ (TGF- $\beta$ ), epidermal growth factor receptor (EGF-R), prolactin receptor (PRL-R), interleukin $I \alpha$ (IL-1 $\alpha$ ), and interleukin 6 (IL-6) (Fig. 5). There was a significant effect of gestational age on the expression of oestrogen receptor $\alpha$ (increase from day 100 to day 185 of gestation; $P<0.003$ ) and TGF- $\beta$ (increase from day 100 to day 185 of gestation; 


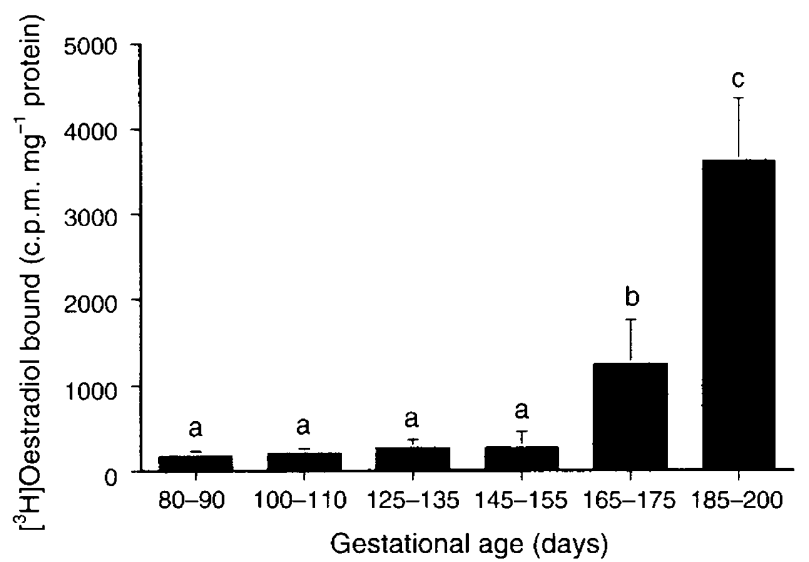

Fig. 3. Means \pm SEM of specific $\left[{ }^{3} \mathrm{H}\right.$ ]oestradiol binding in uterine tissue homogenates. Data were collected from several individuals sampled independently and then results were grouped together to reflect 10 day intervals between day 80 and day 200 of gestation. Before day 110 of gestation, means represent measurements of multiple samples pooled from two or three individuals of similar age. At other times, means represent independent measurements of samples taken from at least three individuals. There was no significant ligand binding activity until day 155 of gestation. There were significant increases from day 155 to day 165 of gestation ( ${ }^{a} P<0.031$ ), from day 165 to day 185 of gestation ( ${ }^{b} P<0.03$ ), and from day 185 to day 200 of gestation $\left({ }^{c} P<0.028\right.$ ).

$P<0.02$ ). In addition, EGF-R, PRL-R, IL- $1 \alpha$, and IL- 6 all tended to increase from days $100-110$ to days $185-200$ of gestation. There was no effect of oestradiol treatment on uterine explants from fetuses at days $100-110$ of gestation $(P=0.71)$. At days 185-200 of gestation, there was an overall effect of oestradiol $(P<0.014)$. Oestradiol treatment resulted in increased expression of mRNA encoding oestrogen receptor $\alpha(P<0.02)$ and decreased expression of TGF- $\beta(P<0.014)$. EGF-R, PRL-R, IL- $1 \alpha$, and IL- 6 all tended to decrease after oestradiol treatment for $24 \mathrm{~h}$ (Fig. 5).

Fetal uteri also expressed retinoic acid receptor (RAR) isoforms $\alpha, \beta$, and $\gamma$ (Fig. 6). Messenger RNA encoding RAR isoforms $\alpha$ and $\beta$ tended to be expressed at greater concentrations at days $185-200$ than at days 100-110 of gestation $(P<0.08)$ and there were significant overall effects of hormone treatments on expression $(P<0.001)$. At days $100-110$ of gestation, there was no effect of treatment with oestradiol; at days 185-200 of gestation, oestradiol treatment tended to increase expression of RAR- $\beta \quad(P<0.08)$. Representative RT-PCR products were excised from agarose gels, subcloned, and subsequently tested by dideoxy chain termination sequencing (Applied Biosystems, Model 373A Automated Sequencer, OSU Recombinant DNA/Protein Resource Facility). The identity of each product was verified in a BLAST sequence homology analysis (Altschul et al., 1990). The sequence of bovine RAR isoforms exhibited the greatest homology with the pig RAR isoform sequences, followed by the human sequences. Bovine RAR- $\alpha$, RAR- $\beta$, and RAR- $\gamma$ diverged from the pig sequence by $5 \%, 2 \%$, and $3 \%$, over 391,336 , and 301 base pairs, respectively.

Total RNA was prepared from fetal and maternal tissues, as well as from culture cell lines Rat $1+$ oestrogen receptor (a positive control for oestrogen receptor expression; Kaneko et al., 1993) and $\mathrm{GH}_{3}$ (a positive control for oestrogen receptor and progesterone receptor expression) and subjected to RT-PCR to explore the lack of expression of progesterone receptor in the bovine fetus uterus. While mRNA encoding oestrogen receptor $\alpha$ was detected by RT-PCR in all tissues examined, mRNA encoding progesterone receptor was detected only in maternal intercaruncular endometrium and the positive control cell line (Fig. 7). The results suggest that expression of mRNA encoding progesterone receptor was either absent, or very low, in the fetal uterus and placenta and, further, that expression of mRNA encoding progesterone receptor was not responsive to oestradiol stimulation.

\section{Transfection of pERE15 and CAT assay}

Radioactivity was $284 \pm 19$ c.p.m. in the organic phase in the absence of cell lysates after partitioning, $3813 \pm 200$ c.p.m. in transfected cells in the absence of oestradiol treatment, and $6057 \pm 367$ c.p.m. in transfected cells after oestradiol treatment. These data further suggest that during the last half of the second third of pregnancy, fetal uteri exhibited an oestrogenic hormone response, and that the observed responses to oestradiol were mediated through the oestrogen receptor-ERE interactions associated with genomic responses to oestrogens.

\section{Discussion}

The objectives of this study were: to establish the gestational age at which the mRNA encoding oestrogen receptor $\alpha$ appeared; to relate the presence of the mRNA to the expression of oestrogen receptor $\alpha$ protein as determined by ligand binding activity; and to relate the appearance of oestrogen receptor $\alpha$ to the establishment of a specific functional hormone response. Messenger RNA encoding oestrogen receptor was expressed in the bovine fetal uterus before day 65 of gestation and there was a significant increase in mRNA encoding oestrogen receptor $\alpha$ between day 100 and day 185 of gestation $(P<0.003)$. In addition, mRNA encoding oestrogen receptor $\alpha$ was detected by RT-PCR in placental membranes and cotyledons. No mRNA encoding oestrogen receptor $\alpha$ was observed in testes, or in vasa deferentia and associated tissue from male fetuses between day 105 and day 120 of gestation. This result differed from that reported in mice, in which oestrogen receptor appeared in the reproductive tracts of both male and female fetuses during the sexually ambiguous stage of reproductive tract development and remained until the end of gestation (Greco et al., 1991, 1992). In spite of the presence of mRNA encoding oestrogen receptor $\alpha$ in females, $\left[{ }^{3} \mathrm{H}\right]-$ oestradiol binding was not evident in fetal uteri until after day 155 of gestation. After that time, $\left[{ }^{3} \mathrm{H}\right]$ oestradiol binding was specific and saturable; the results of Scatchard analysis reflected the presence of a single binding site with a dissociation constant $<0.3 \mathrm{nmol} \mathrm{l}^{-1}$. In addition, a specific, hormoneinducible response to oestradiol was observed in fetal uterine tissue collected at the end of the second third of pregnancy. This response to oestradiol was observed in three separate analyses: in the increased total RNA present after oestradiol 


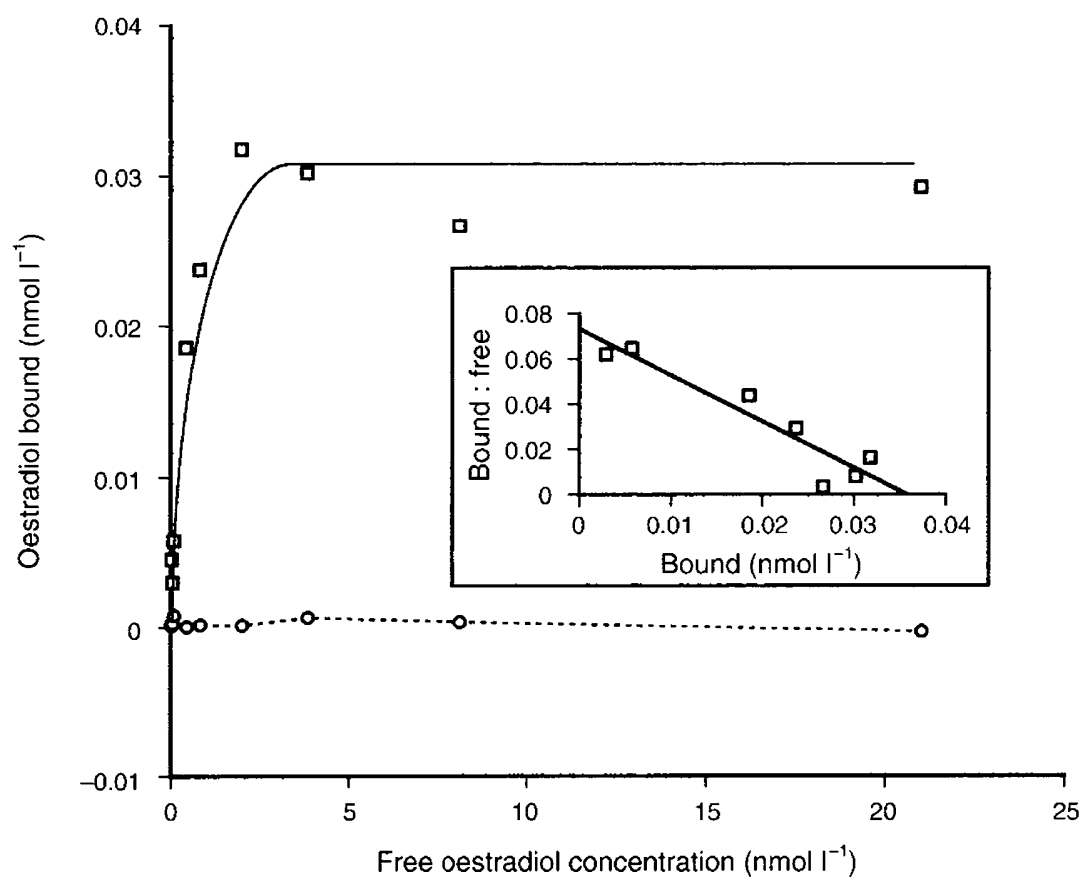

Fig. 4. Plots of specific $\left[{ }^{3} \mathrm{H}\right]$ oestradiol binding versus increasing concentrations of oestradiol in fetal uterine homogenate from day 185 of gestation showed saturable binding $(\square)$. The oestradiol binding sites were saturated at a concentration $<3 \mathrm{nmoll}^{-1}$. In a pooled sample from uteri at day 100 of gestation, no $\left[{ }^{3} \mathrm{H}\right]$ oestradiol binding above background was detected $(\mathrm{O})$. Inset: Specific $\left[{ }^{3} \mathrm{H}\right]$ oestradiol binding data from an individual at day 185 of gestation were plotted as a Scatchard transformation. Oestrogen receptor $\alpha$ appeared to bind oestradiol as a single site with a dissociation constant $<0.3 \mathrm{nmol} \mathrm{I}^{-1}$

treatment at day 185 of gestation; in the alteration of expression of specific gene products, including the oestrogen receptor $\alpha$ itself, observed in a semi-quantitative PCR amplification; and in the upregulation of gene expression from a transiently transfected reporter gene construct, pERE15 (Klock et al., 1987). There was no detectable response to oestradiol by fetal uterine tissue collected early in the second third of pregnancy.

Despite the presence of apparently functional oestrogen receptor $\alpha$ in the bovine fetal uterus by day 165 of gestation, mRNA encoding progesterone receptor was not detected by RT-PCR. Oestradiol upregulates progesterone receptor expression in the bovine uterus (Zelinski et al., 1982) as well as in several other species, including sheep (Miller et al., 1977; Spencer and Bazer, 1995), rats (Kraus and Katzenellenbogen, 1993), guinea-pigs (Pasqualini et al., 1980) and mice (Hagihara et al., 1994). Stable expression of ectopic oestrogen receptor $\alpha$ in a rat embryonic fibroblast cell line resulted in oestradioldependent upregulation of expression of the ordinarily silent progesterone receptor gene (Kaneko et al., 1993). In the present study, mRNA encoding progesterone receptor was not observed either in tissue samples prepared directly from fetuses or in tissues placed in explant culture and incubated in the presence of nanomolar concentrations of oestradiol. Messenger RNA encoding progesterone receptor was detectable under similar conditions in positive control tissue samples (maternal uterine endometrium), in a rat culture cell line, and in RT-PCR reactions using cloned $\mathrm{cDNA}$ encoding progesterone receptor as a positive control, suggesting that failure to detect
mRNA encoding progesterone receptor in fetal uterine tissues or dispersed fetal uterine cells (data not shown) is truly representative of the lack of detectable expression.

The developing fetus is exposed to significant concentrations of oestrogens during pregnancy (Challis et al., 1974; Robertson and King, 1979; Evans and Wagner, 1981; Robertson et al., 1985; Tsumagari et al., 1993). The roles of these oestrogens within the fetal uterus remain unclear, although various activities may be suggested, including the modulation of protein synthesis and secretion (Salamonsen et al., 1985; Garrett et al., 1988), the regulation of placental fluid exchange, electrolyte transport and the protein and nutrient content in the allantoic fluid (Bazer, 1989), angiogenesis, and the maintenance of vascular tone. Oestrogens may be involved in the formation of the uterine glands in the fetus observed in the final third of pregnancy (Atkinson et al., 1984). Failure to increase the oestrogen concentration in the fetal-placental compartment in the last weeks of pregnancy results in delayed parturition in several species (Challis and Olson, 1988). The uptake of circulating oestradiol from the blood by the developing fetal rat brain (Montano et al., 1995) suggests that circulating oestrogens exert biological effects within tissues of the developing fetus.

The absence of progesterone receptor may be a means of avoiding antagonism of oestrogen-induced effects on tissue growth and differentiation. Progesterone inhibits oestrogen receptor expression (Brenner and West, 1975; Spencer and Bazer, 1995). Progestin-induced suppression of oestrogen 
(a)

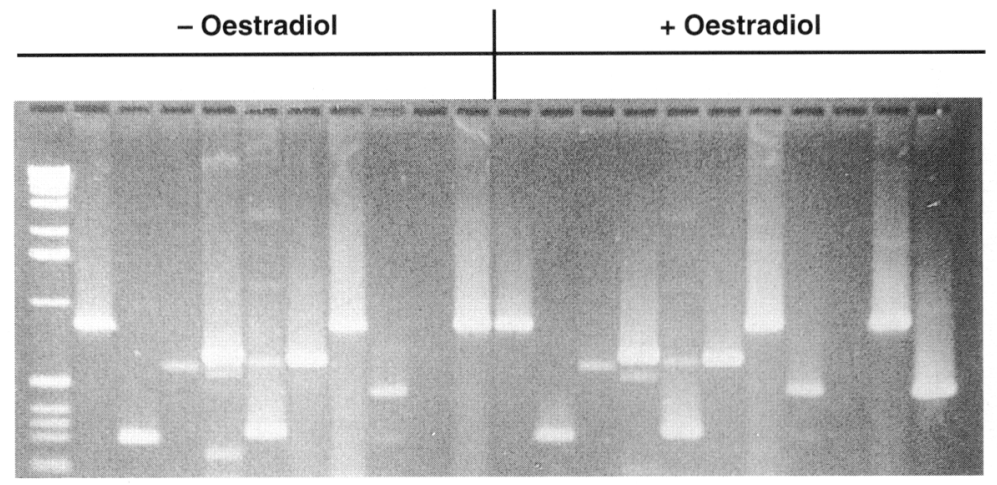

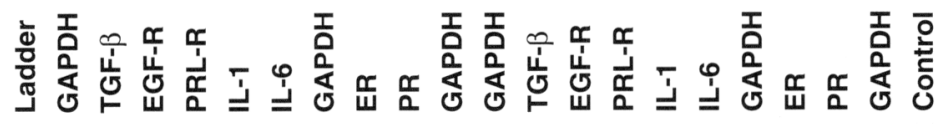

\section{Day 100 of} gestation

$517 / 506=$
$396=$
$344=$
$298=$
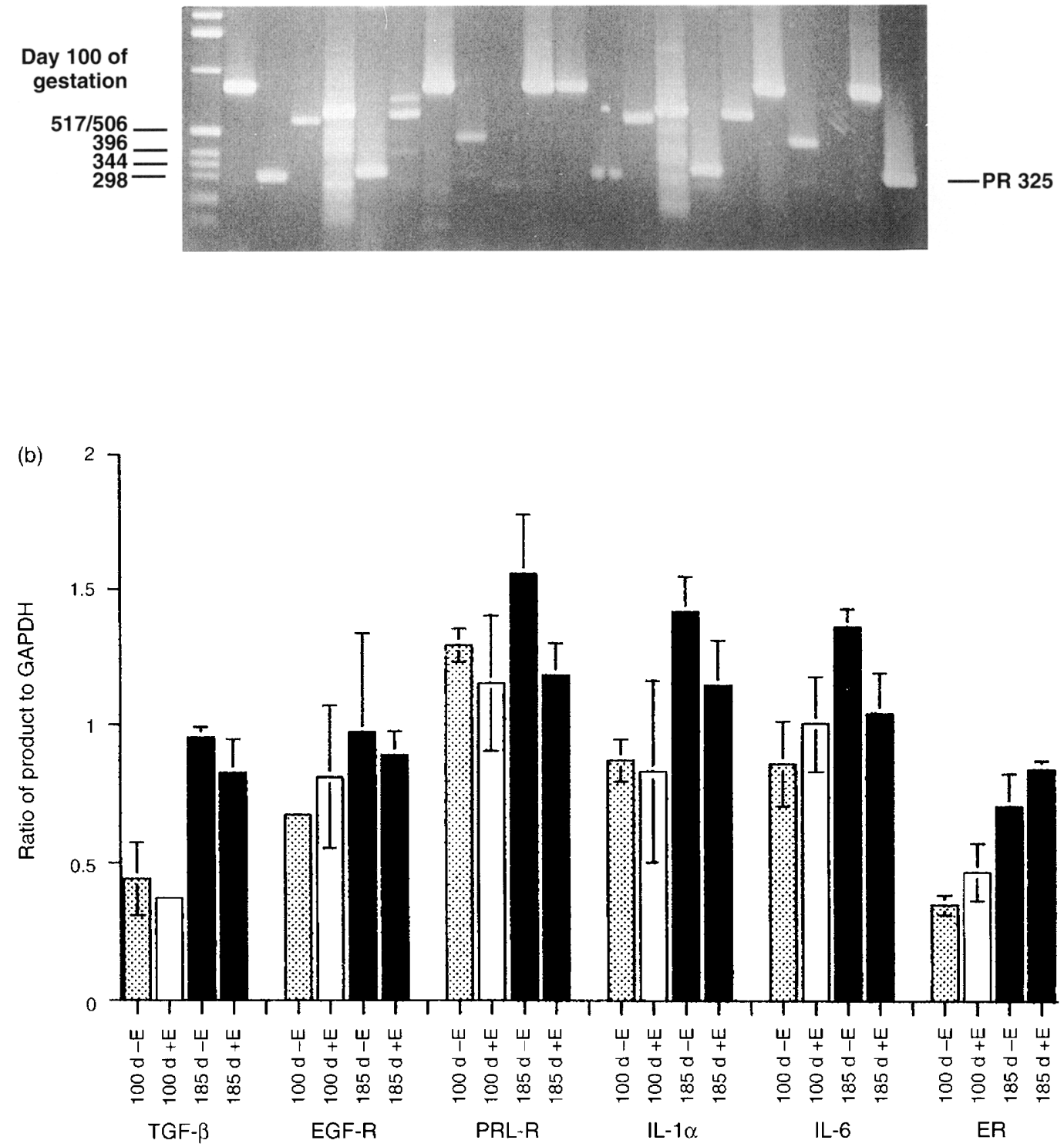
(a)

Retinoic acid
receptor $\alpha$

\section{Retinoic acid receptor $\beta$}

\section{Retinoic acid receptor $\gamma$}

$$
\begin{array}{ll}
\text { Day } 185 \text { of } & \text { Day } 100 \text { of } \\
\text { gestation } & \text { gestation }
\end{array}
$$
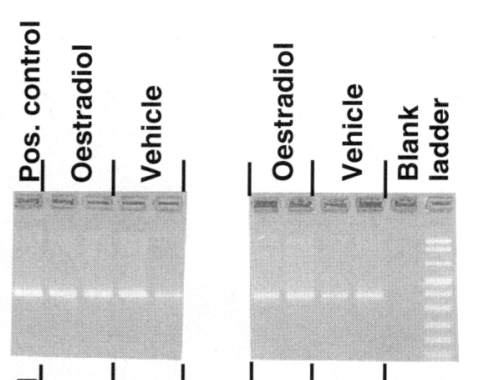

$\begin{array}{ll}\text { (b) } & 1.5 \\ \text { I } & \end{array}$

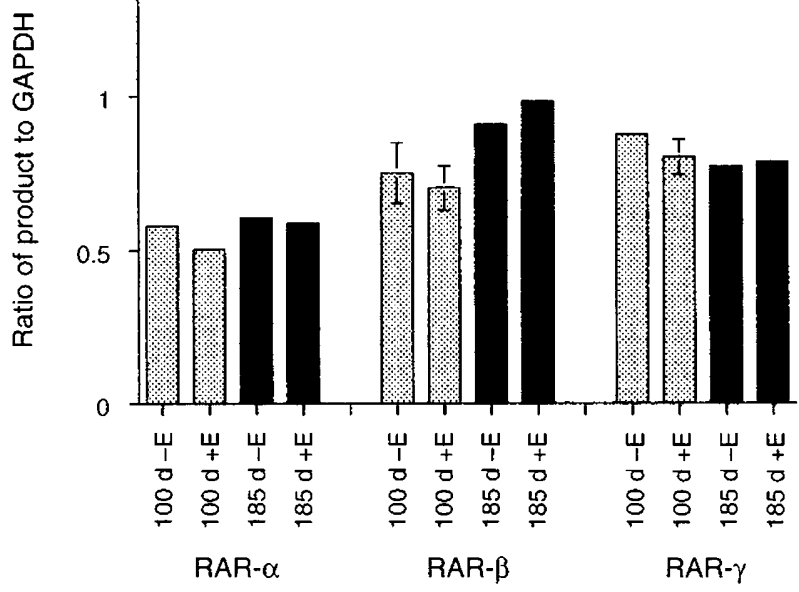

Fig. 6. (a) Representative ethidium bromide-stained agarose gel of RT-PCR analysis to detect the presence of specific mRNAs encoding retinoic acid receptor (RAR) in fetal uterine explants collected at days 100-110 or days 185-200 of gestation and incubated in the presence of $1.0 \mathrm{nmol}$ oestradiol $\mathrm{l}^{-1}$ (E) or ethanol vehicle. Gels were examined by scanning densitometry, and results are presented in (b) as the ratio of each amplified cDNA product to the glyceraldehyde-3-phosphate dehydrogenase (GAPDH) loading control. Fetal uterine explants expressed detectable concentrations of mRNA for RAR isoforms $\alpha, \beta$, and $\gamma$. (b) Messenger RNA for RAR isoforms $\alpha$ and $\beta$ tended to be expressed at greater concentrations at days 185-200 than at days 100-110 of gestation $(P<0.08)$ and there were significant overall effects of hormone treatments on expression $(P<0.001)$. At days 100-110 of gestation, there was no effect of treatment with oestradiol; at days $185-200$ of gestation, oestradiol treatment resulted in increased expression of RAR- $\beta(P<0.08)$.

receptor expression and other oestrogen-induced activities may have deleterious effects in the fetus, where rapid synthesis of proteins and other effects associated with oestrogen stimulation of cell growth and differentiation are critical. Lack of upregulation of progesterone receptor expression in response to oestradiol in the fetal uterus may be due to the absence of some tissue-specific transcription factor not yet expressed in the second third of pregnancy, or to the requirement for modification of the chromatin structure associated with the progesterone receptor promoter that has not yet occurred, that

Fig. 5. (a) Representative ethidium bromide-stained agarose gels of RT-PCR analysis to detect the presence of specific mRNAs encoding oestrogen receptor (ER) $\alpha$ and progesterone receptor (PR) in fetal uterine explants collected at days $100-110$ or days $185-200$ of gestation and incubated in the presence of $1.0 \mathrm{nmol}$ oestradiol $\mathrm{l}^{-1}$ (E) or ethanol vehicle. Gels were examined by scanning densitometry, and results are presented in (b) as the ratio of each amplified cDNA product to the glyceraldehyde-3-phosphate dehydrogenase (GAPDH) loading control. Fetal uterine explants expressed detectable concentrations of mRNA encoding oestrogen receptor $\alpha$, transforming growth factor $\beta$ (TGF- $\beta$ ), epidermal growth factor receptor (EGF-R), prolactin receptor (PRL-R), interleukin $1 \alpha$ (IL-1 $\alpha$ ), and interleukin- 6 (IL-6); however, mRNA encoding progesterone receptor was not detectable in either vehicle-treated or oestradiol-treated explants, regardless of gestational age. (b) There was a significant effect of gestational age on the expression of oestrogen receptor $\alpha$ (increase from day 100 to day 185 of gestation; $P<0.003$ ) and TGF- $\beta$ (increase from day 100 to day 185 of gestation; $P<0.02$ ). In addition, EGF-R, PRL-R, IL-1 $\alpha$, and IL- 6 all tended to increase from days $100-110$ to days 185-200 of gestation. There was no effect of oestradiol treatment on uterine explants from fetuses at days 100-110 of gestation $(P=0.71)$. At days $185-200$ of gestation, there was an overall effect of oestradiol $(P<0.014)$ that resulted in increased expression of mRNA encoding oestrogen receptor $\alpha(P<0.02)$ and decreased expression of TGF- $\beta(P<0.014)$. EGF-R, PRL-R, IL-I $\alpha$, and IL- 6 all tended to decrease after oestradiol treatment for $24 \mathrm{~h}$. 


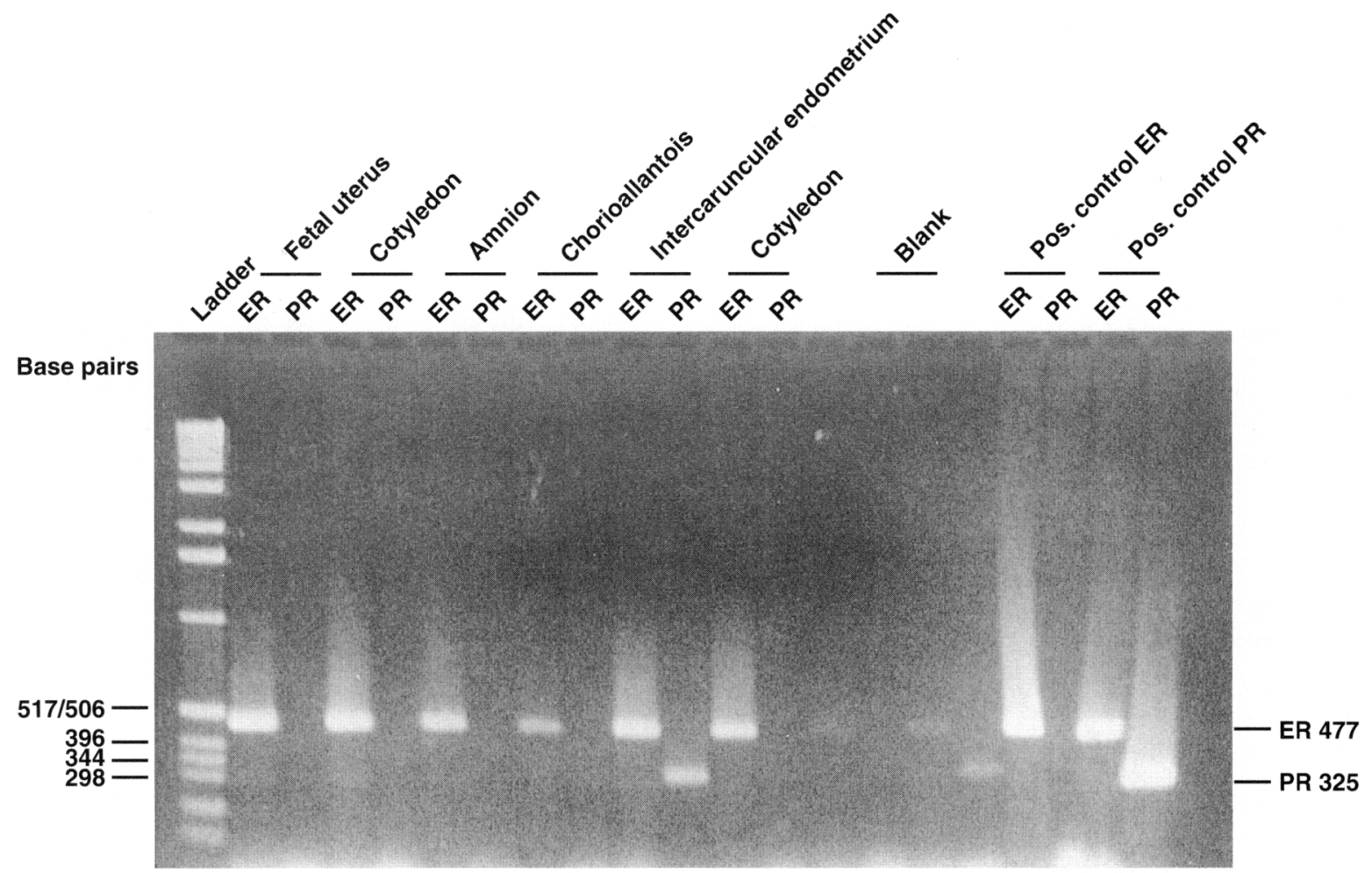

Fig. 7. Representative ethidium bromide-stained agarose gel of RT-PCR analysis to detect the presence of specific mRNAs encoding oestrogen receptor $(E R) \alpha$ and progesterone receptor (PR) in fetal and maternal tissues at day 180 of gestation. RNA was prepared from fetal and maternal tissues, as well as from culture cell lines Rat1 + oestrogen receptor (a positive control for oestrogen receptor $\alpha$ expression; lanes 16,17 ) and GH 3 (a positive control for oestrogen receptor $\alpha$ and progesterone receptor expression; lanes 18, 19) to investigate the lack of expression of progesterone receptor in the uterus of the bovine fetus. While mRNA encoding oestrogen receptor $\alpha$ was detected by RT-PCR in all tissues examined, mRNA encoding progesterone receptor was detected only in maternal intercaruncular endometrium and the positive control cell line. The reaction blank (lanes 14,15 ) was subjected to RT-PCR in the absence of RNA.

is, the appearance of characteristic DNase I hypersensitive regions.

'The appearance of oestrogen receptor $\alpha$ in the fetal reproductive tract may involve regulation by oestrogens. Notable increases in unconjugated oestrone and oestradiol in the allantoic and amniotic fluid of calves occurred between day 130 and day 190 of gestation (Robertson and King, 1979), and in the blood of female fetuses between day 150 and day 200 of gestation (Challis et al., 1974), coincident with the appearance of oestrogen receptor $\alpha$ in the present study. Oestrogens increased the oestrogen receptor concentration in rat uterine cells in vitro (Kassis et al., 1984b) and in adult rats (Sahlin et al., 1994) and neonatal mice in vivo (Yamashita et al, 1990). Changes in oestrogen receptor protein and mRNA concentration in the uterine endometrium were correlated with plasma oestradiol during the oestrous cycle in sheep (Miller et al., 1977; Spencer and Bazer, 1995) and mice (Bergman et al., 1992). Regulation of oestrogen receptor expression may occur, in part, through a post-transcriptional mechanism in which control is exerted over mRNA stability or translational efficiency. Post-transcriptional control has been implicated in oestrogen-induced upregulation of oestrogen receptor in sheep endometrium (Ing et al., 1996) and in oestrogen-induced downregulation of oestrogen receptor in MCF-7 cells (Saceda et al., 1989).
In addition to expression of oestrogen receptor $\alpha$ and progesterone receptor, the present study examined the occurrence of retinoic acid receptors, TGF- $\beta$, several growth factor receptors, and the cytokines, IL-I $\alpha$ and IL- 6 , in the fetal uterus; each of these is expressed in the uterus of various species, including cattle. These data must be interpreted with caution since results were obtained in an explant culture containing many cell types that may interact in complex ways to produce the observed results. However, these data demonstrate agerelated alterations in expression of these markers as well as responses to oestradiol at day 185 of gestation; no response was observed at day 100 of gestation, before expression of oestrogen receptor $\alpha$. Oestradiol induces RAR- $\alpha$ and RAR- $\gamma$ in mouse cervical epithelium (Celli et al., 1996) and increases RAR- $\alpha$ in human breast carcinoma cells (Rishi et al., 1995). Oestradiol effects in the mouse uterus are mediated, in part, by EGF and human fetal uteri express EGF-R (Glatstein and Yeh, 1995). Oestradiol-induced downregulation of IL- 6 has been demonstrated in several cell types, including endometrial stromal cells (Ray et al., 1994).

Taken together, these data suggest a hypothesis in which fetal gonadal and placental oestrogens probably have no role in duct morphogenesis in the bovine fetus, but may contribute, perhaps beginning at about day 150 of gestation, to the induction of oestrogen receptor $\alpha$, probably 
via a post-transcriptional control mechanism. Thus, control of oestrogen receptor $\alpha$ expression may involve a 'feed forward' model in which there is a continuous increase in mRNA encoding oestrogen receptor $\alpha$ in the fetal uterus from the first through to the end of the second third of pregnancy, possibly as a result of oestrogen-mediated stabilization of the mRNA. When mRNA encoding oestrogen receptor $\alpha$ reaches some threshold steady state concentration, the rate of translation to synthesize oestrogen receptor $\alpha$ protein exceeds the rate of degradation of the message, and the oestrogen receptor $\alpha$ protein reaches a detectable concentration. The presence of oestrogen receptor $\alpha$ may then contribute to further, tissuespecific differentiation.

In conclusion, at the end of the second third of pregnancy in cattle, the fetal uterus exhibited a functional hormone response mediated through oestrogen receptor $\alpha$ interactions at the genomic DNA to modify specific target gene expression; this response system began to develop after the midpoint of the second third of pregnancy.

This study was supported by USDA NRICGP Grant 94-372060937. The authors thank R. D. Geisert, Oklahoma State University, for helpful comments. Several of the primer sequences used in PCR were provided by L. A. Schuler, University of Wisconsin, Madison. The authors also thank the staff of Wellington Quality Meats, Wellington, $\mathrm{KS}$, USA for their assistance and donation of materials used in the study. The authors acknowledge the Oklahoma State University Recombinant DNA/Protein Resource Facility for the synthesis of synthetic oligonucleotides and the sequencing of cloned cDNA.

\section{References}

Altschul S, Gish W, Miller W, Myers E and Lipman D (1990) Basic local alignment search tool Journal of Molecular Biology 215 403-410

Atkinson B, King G and Amoroso E (1984) Development of the caruncular and intercaruncular regions in the bovine endometrium Biology of Reproduction 30 $763-774$

Bazer F (1989) Allantoic fluid: regulation of volume and composition. In Fetal and Neonatal Body Fluids pp 135-155 Eds R Brace, M Ross and J Robillard. Perinatology Press, Ithaca, NY

Beato M (1989) Gene regulation by steroid hormones Cell 56 335-344

Bergman M, Schachter B, Karelus K, Combatsiaris E, Garcia T and Nelson J (1992) Up-regulation of the uterine estrogen receptor and its messenger ribonucleic acid during the mouse estrous cycle: the role of estradiol Endocrinology 130 1923-1930

Bradford M (1976) A rapid and sensitive method for the quantitation of microgram quantities of protein utilizing the principle of protein-dye binding Analytical Biochemistry 72 248-254

Brenner RM and West NB (1975) Hormonal regulation of the reproductive tract in female mammals Annual Review of Physiology 37 273-302

Celli G, Darwiche N and De Luca L (1996) Estrogen induces retinoid receptor expression in mouse cervical epithelia Experimental Cell Research 226 273-282

Challis JRG and Olson DM (1988) Parturition. In The Physiology of Reproduction pp 2177-2216 Eds E Knobil and JD Neill. Raven Press, New York

Challis JRG, Kim CK, Naftolin F, Judd HL, Yen SSC and Benirschke K (1974) The concentrations of androgens, oestrogens, progesterone and luteinizing hormone in the serum of foetal calves throughout the course of gestation Journal of Endocrinology 60 107-115

Chomczynski P and Sacci N (1987) Single step method of RNA isolation by acid guanidinium thiocyanate-phenol-chloroform extraction Analytical Biochemistry 162 156-159

Diekman MA and Green ML (1992) Mycotoxins and reproduction in domestic livestock Joumal of Animal Science 70 1615-1627

Evans G and Wagner WC (1981) In vitro oestrogen synthesis by bovine placenta during pregnancy and induced parturition Acta Endocrinology 98 $119-125$
Garrett JE, Geisert RD, Zavy MT and Morgan GL (1988) Evidence for maternal regulation of early conceptus growth and development in beef cattle Journal of Reproduction and Fertility 84 437-446

Glatstein IZ and Yeh J (1995) Ontogeny of the estrogen receptor in the human fetal uterus Journal of Clinical Endocrinology and Metabolism 80 958-964

Gorski J (1986) The nature and development of steroid hormone receptors Experientia 42 744-750

Greco TL, Furlow JD, Duello TD and Gorski J (1991) Immunodetection of estrogen receptors in fetal and neonatal female mouse reproductive tracts Endocrinology 129 1326-1332

Greco TL, Furlow JD, Duello TD and Gorski J (1992) Immunodetection of estrogen receptors in fetal and neonatal male mouse reproductive tracts Endocrinology $130421-429$

Hagihara K, Wu-Peng XS, Funabashi T, Kato J and Pfaff DW (1994) Nucleic acid sequence and DNase hypersensitive sites of the $5^{\prime}$ region of the mouse progesterone receptor gene Biochemical and Biophysical Research Communications 205 1093-1101

Herbst AL, Ulfelder H and Poskanzer DC (1971) Adenocarcinoma of the vagina New England Journal of Medicine 284 878-881

Herbst AL, Cole R, Colton T, Robboy SJ and Scully RE (1977) Age-incidence and risk of diethylstilbestrol-related clear cell adenocarcinoma of the vagina and cervix American Journal of Obstetrics and Gynecology 128 43-48

Horwitz KB, Costlow ME and McGuire WL (1976) MCF-7: a human breast cancer cell line with estrogen, androgen, progesterone and glucocorticoid receptors Steroids 26 785-795

Hou Q and Gorski J (1993) Estrogen receptor and progesterone receptor genes are expressed differently in mouse embryos during preimplantation development Proceedings of the National Academy of Sciences USA 90 9460-9464

Ing NH, Spencer TE and Bazer FW (1996) Estrogen enhances endometrial estrogen receptor gene expression by a posttranscriptional mechanism in the ovariectomized ewe Biology of Reproduction 54 591-599

Kaneko KJ, Gelinas C and Gorski J (1993) Activation of the silent progesterone receptor gene by ectopic expression of estrogen receptors in a rat fibroblast cell line Biochemistry 32 8348-8359

Kassis JA, Sakai D, Walent JH and Gorski J (1984a) Primary cultures of estrogen-responsive cells from rat uteri: induction of progesterone receptors and a secreted protein Endocrinology 114 1558-1566

Kassis JA, Walent JH and Gorski J (1984b) Estrogen receptors in rat uterine cell cultures: effects of medium on receptor concentration Endocrinology 115 $762-769$

Katzenellenbogen BS (1996) Estrogen receptors: bioactivities and interactions with cell signalling pathways Biology of Reproduction 54 287-293

Klock G, Strahle U and Schütz G (1987) Oestrogen and glucocorticoid responsive elements are closely related but distinct Nature 329 734-736

Kraus WL and Katzenellenbogen BS (1993) Regulation of progesterone receptor gene expression and growth in the rat uterus: modulation of estrogen actions by progesterone and sex steroid hormone antagonists Endocrinology 132 2371-2379

Livingston AL (1978) Forage plant estrogens Journal of Toxicology and Environmental Health 4 30I-324

McLachlan JA, Newbold RR and Bullock B (1975) Reproductive tract lesions in male mice exposed prenatally to diethylstilbestrol Science 190 991-992

McLachlan JA, Newbold RR and Bullock BC (1980) Long-term effects on the female mouse genital tract associated with prenatal exposure to diethylstilbestrol Cancer Research 40 3988-3999

Miller BG, Murphy L and Stone GM (1977) Hormone receptor levels and hormone. RNA and protein metabolism in the genital tract during the estrous cycle of the ewe Journal of Endocrinology 73 91-98

Montano MM, Welshons WV and vom Saal FS (1995) Free estradiol in serum and brain uptake of estradiol during fetal and neonatal sexual differentiation in female rats Biology of Reproduction 53 1198-1207

Nestor PV, Forde RC, Webb P and Gannon F (1994) The genomic organisation, sequence and functional analysis of the 5 ' flanking region of the chicked estrogen receptor gene Journal of Steroid Biochemistry and Molecular Biology $50 \quad 121-130$

Newbold RR, Bullock B and McLachlan JA (1983) Exposure to diethylstilbestrol during pregnancy permanently alters the ovary and oviduct Biology of Reproduction 28 735-744

Newbold RR, Bullock BC and McLachlan JA (1985) Lesions of the rete testis in mice exposed prenatally to diethylstilbestrol Cancer Research 45 5145-5150

Newbold RR, Bullock BC and McLachlan JA (1986) Adenocarcinoma of the rete testis: diethylstilbestrol-induced lesions of the mouse rete testis American Journal of Patholology 125 625-628 
O'Malley B (1990) The steroid receptor superfamily: more excitement predicted for the future Molecular Endocrinology 4 363-369

Pasqualini JR, Sumida C, Nguyen BL, Tardy J and Gelly C (1980) Estrogen concentrations and effect of estradiol on progesterone receptors in the fetal and new-born guinea pigs Journal of Steroid Biochemistry 12 65-72

Ray A, PreFontaine K and Ray P (1994) Down-modulation of interleukin- 6 gene expression by $17 \beta$-estradiol in the absence of high affinity DNA binding by the estrogen receptor Journal of Biological Chemistry 26912 940-12 946

Rexroad CE, Jr Casida LE and Tyler WJ (1974) Crown-rump length of fetuses in purebred Holstein-Friesian cows Journal of Dairy Science 57 346-347

Rishi A, Shao Z-M, Baumann R, Li X-S, Sheikh S, Kimura S, Bashirelahi N and Fontana J (1995) Estradiol regulation of human retinoic acid receptor $\alpha$ gene in human breast carcinoma cells is mediated via an imperfect halfpalindromic estrogen response element and Sp1 motifs Cancer Research 55 4999-5006

Robertson HA and King GJ (1979) Conjugated and unconjugated oestrogens in fetal and maternal fluids of the cow throughout pregnancy Journal of Reproduction and Fertility 55 463-470

Robertson HA, Dwyer RJ and King GJ (1985) Oestrogens in fetal and maternal fluids throughout pregnancy in the pig and comparisons with the ewe and cow Journal of Endocrinology 106 355-360

Saceda M, Lippman ME, Lindsey RK, Puente M and Martin MB (1989) Role of an estrogen receptor-dependent mechanism in the regulation of estrogen receptor mRNA in MCF-7 cells Molecular Endocrinology 3 1782-1787

Sahlin L, Norstedt G and Eriksson H (1994) Estrogen regulation of the estrogen receptor and insulin-like growth factor- $I$ in the rat uterus: potential coupling between effects of estrogen and IGF-I Steroids 59 421-430
Salamonsen L, O W, Doughton B and Findlay J (1985) The effects of estrogen and progesterone in vivo on protein synthesis and secretion by cultured epithelial cells from sheep endometrium Endocrinology 117 2148-2159

Scatchard G (1949) The attractions of proteins for small molecules and ions Annals New York Academy of Sciences 51 660-672

Shemesh M (1980) Estradiol-17 $\beta$ biosynthesis by the early bovine fetal ovary during the active and refractory phases Biology of Reproduction 23 577-582

Spencer TE and Bazer FW (1995) Temporal and spatial alterations in uterine estrogen receptor and progesterone receptor gene expression during the estrous cycle and early pregnancy in the ewe Biology of Reproduction $\mathbf{5 3}$ $1527-1543$

Steel R and Torrie J (1980) Principles and Procedures of Statistics: a Biometrical Approach McGraw-Hill, New York

Tsumagari S, Kamata J, Takagi K, Tanemura K, Yosai A and Takeishi M (1993) Aromatase activity and oestrogen concentrations in bovine cotyledons and caruncles during gestation and parturition Journal of Reproduction and Fertility $98631-636$

Weaver GA, Kurtz HJ, Behrens JC, Robinson TC, Sequin BE, Bates FY and Mirocha CJ (1986) Effect of zearalenone on fertility of virgin dairy heifers American Journal of Veterinary Research 47 1395-1397

Yamashita S, Newbold RR, McLachlan JA and Korach KS (1990) The role of the estrogen receptor in uterine epithelial proliferation and cytodifferentiation in neonatal mouse Endocrinology 127 2456-2463

Zelinski MB, Noel P, Weber DW and Stormshak F (1982) Characterization of cytoplasmic progesterone receptors in the bovine endometrium during proestrus and diestrus Journal of Animal Science 55 376-383 